\title{
Crigler-Najjar syndrome type 2
}

INSERM

\section{Source}

INSERM. (1999). Orphanet: an online rare disease and orphan drug data base. CriglerNaijar syndrome type 2. ORPHA:79235

Type 2 Crigler-Najjar syndrome (CNS2) is a hereditary disorder of bilirubin metabolism characterized by unconjug ated hyperbilirubinemia due to reduced and inducible activity of hepatic bilirubin glucuronosyltransferase (GT). CNS2 is a milder form of CNS than CNS1 (see these terms). 